\title{
Developing Interactive Teaching Materials of Fantasy Story Text with Character EducationBased for Seventh Grade Students at MTs Miftahussalam Medan
}

\author{
ElsyaFitriUtami, S.Pd \\ Dr. MutsyuhitoSolin, M.Pd. \\ Dr. DaulatSaragi, M.Hum.
}

\begin{abstract}
The background of this study is the importance of instilling character education in learning and the use of interactive teaching materials which are still seldom used. This study aims to: (1) Describe the result of developing interactive teaching materials of fantasy story text with character educationbased for seventh grade students at MTS MiftahussalamMedan. (2) Describe the appropriateness of interactive teaching materials of fantasy story text with character education-based for seventh grade students at MTS Miftahussalam Medan. (3) Describe the effectiveness of students by using interactive teaching materials of fantasy story text with character education-based for seventh grade students at MTS Miftahussalam Medan. This study used Research and Development $(R \& D)$ based on Hanafin\& Peck Model. The subject of study was the seventh grade students at MTS Miftahussalam Medan. The result of study stated that the result of students' learning increased $13.79 \%$. Before that, in the pretest conducted was gained the average as 70.28 then in the posttest gained the average as 84.07 . The result also demonstrated that interactive teaching materials of fantasy story text with character education-based for seventh grade students at MTS Miftahussalam Medan were appropriate to be used as the independent learning materials.
\end{abstract}

Key Words: Teaching Materials, Interactive, FantasyStory Text, Character Education.

\section{INTRODUCTION}

As one of the text types which is learnt in the seventh grade of Junior High School related to Curriculum 2013 is fantasystory text. The materials are about the fantasy story texts which are commonly learnt only based on text book "Bahasa Indonesia Kelas VII SMP/MTs Kurikulum 2013 EdisiRevisi 2016" and there is no the other interactive teaching materials. Therefore, it is needed to develop teaching materials to attract the students' interest especially developing of fantasy story text materials.
Based on the result of observation, the process of learning in the school still focused on the text book, besides the teacher also still used whiteboard and worksheet (LKS), hence the students were not motivated to learn. That things obstructed the effort of optimality learning, such as: (1) the result of students' learning generally only achieved on the lowest mastery level, the students commonly learned by memorizing technique, explanation from teacher and books, (2) the sources which were used by students limited to the explanation from teacher and a bit of hand book, (3) in teaching activity, teacher seldom stimulated the students' learning activity optimally.

Therefore, it is needed to use appropriate interactive teaching materials related to curriculum 2013 with character education implemented by teachers in the school. The interactive teaching materials will motivate the students in following the learning process. Very clearly, interactive teaching materials play an important role in the education process of students and teachers in particular.

\section{RESEARCH METHODOLOGY}

In the research of developing teaching materials of fantasy story text with character education-based, researcher used Research and Development $(R \& D)$ based on Hanafin\& Peck Model which was found the book of "Model PenelitianPengembangan" written by I Made Tegeh and friends.

Hanafin\& Peck Model consists of three main processes. The first process of this model is the stage of research needs, continued then the stage of design and the third one is development and implementation. In all stages involve the process of evaluation and revision, Tegeh (2014:2). Moreover, the stages of this model can be seen on the figure, as follows: 


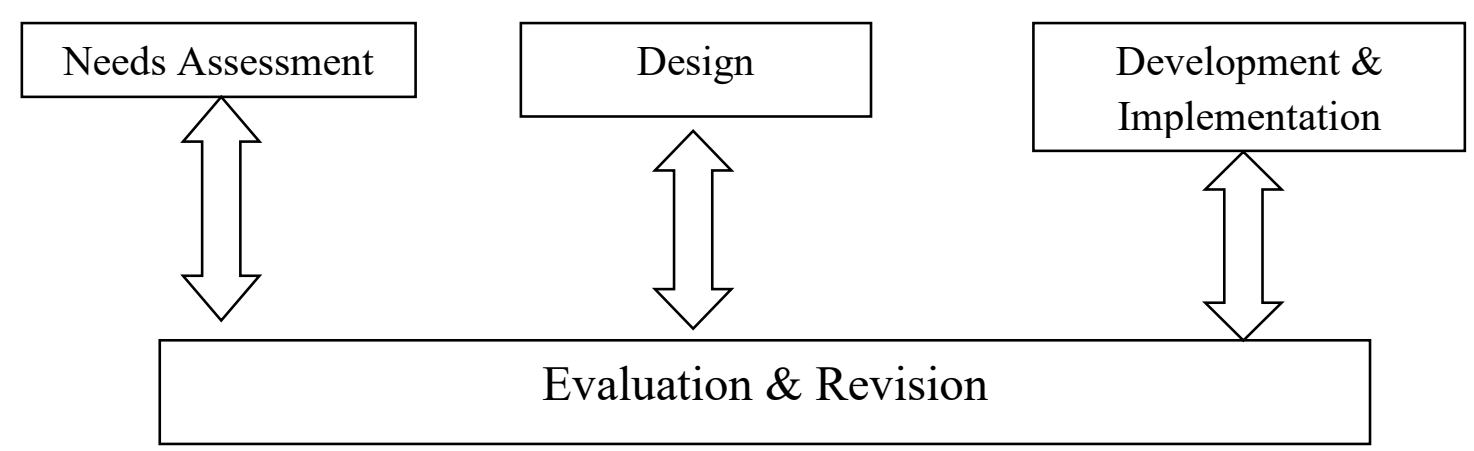

Fig1 :Hanafin \& Peck Model

\section{RESULT AND DISCUSSION}

The discussion of this research result aims to describe the findings of study which have stated before explicitly. The discussion of this study covers about the result of teaching materials development, the appropriateness of learning media, and the result of students' learning.

1. The Result of Developing Fantasy Story Text Learning Media with WEB-based Character Education

The result of Developing Text Learning Media Fantasy Stories with WEB-based Character Education, for instance there is a website which can be accessed on page elsya.000webhostapp.com through internet connection. The content of learning media contains thoroughly, as follows:

1) Home

2) Introduction

3) Learning Activity

4) Video

5) Development

6) Posttest (for the test of multiple choice and essay questions by students)

7) Login (for the administrator of Web)

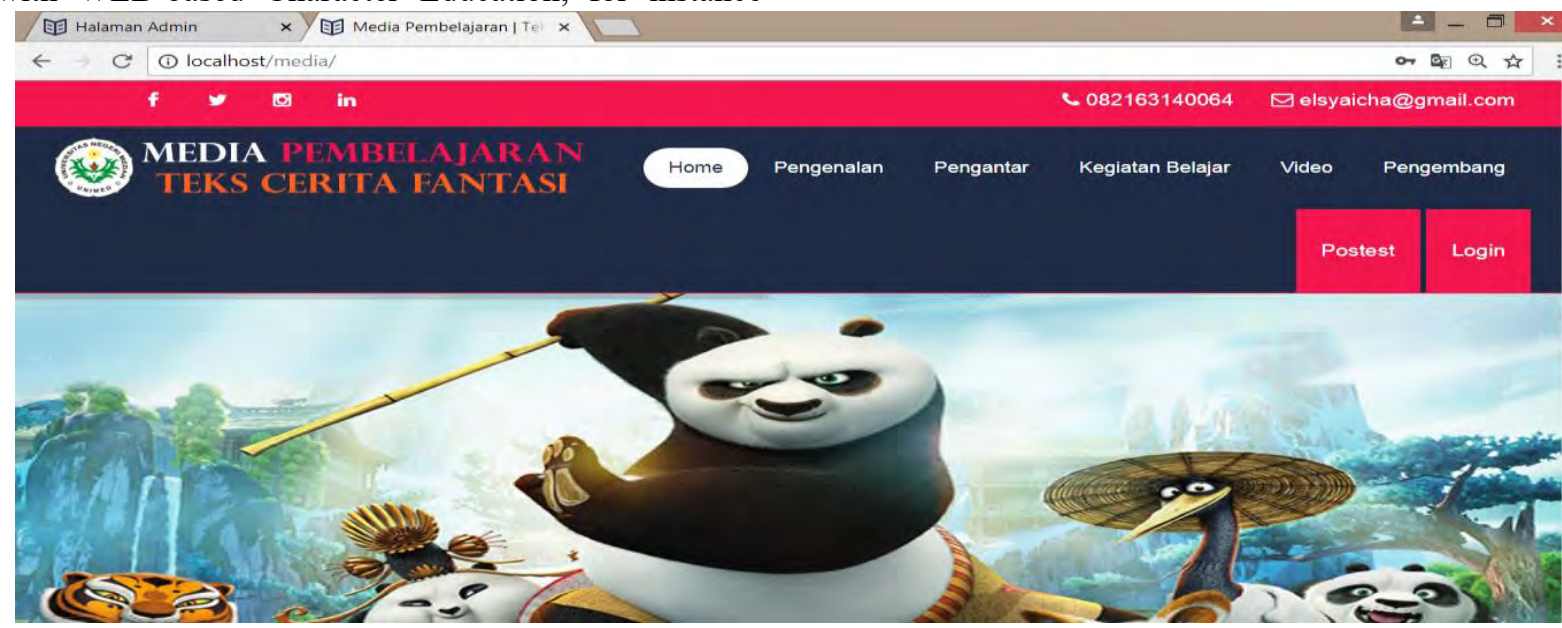

Fig 2: Background of website

\section{The Appropriateness of Teaching Materials}

The research of development conducted by researcher aimed to produce the product such as Web-based learning media on fantasy text for seventh grade students at MTS Miftahussalam Medan. Afterwards, the result of validity of learning media product based web fantasy stories can be specified, as follows:

(1) The result of validity of learning media by material expert stated "Very Good". The result of validity consisted of three aspects in assessing, for instance the appropriateness of content gained the average is $88.39 \%$ with the criteria of "very good", and the appropriateness of material presentation gained $96.42 \%$ with the criteria of "very good", and the appropriateness of language gained $88.48 \%$ with the criteria of "very good". The result of the three aspects stated "Very Good" with the total of average is $91.15 \%$.

(2) The result of validity of learning media by media designer stated "Very Good". The result of validity consisted of three aspects in assessing, for instance, the size of module, the design of module cover and the design of module content. Based on the size of module assessment gained the result of percentage is $100 \%$ with the criteria "very good". Based on the assessment of module cover divided into three parts of assessment, the first assessment based on the cover of module a) the layout of module cover gained the average is $87.5 \%$ with the criteria of "very good" b) the aspect of the use of 
letters was attractive and easy-reading gained the result $100 \%$ with the criteria of "very good" c) the assessment of the illustration of module cover gained the average is $93.75 \%$ with the criteria of "very good". The aspect of the design of module content gained the result of percentage is 81.25 with the criteria of "very good", there are seven parts which are assessed in this part, such as, the result of assessment from each aspect a) the element of harmonious layout gained the result is $95.38 \%$ with the criteria of "very good" b) the element of complete layout gained the result is $93.75 \%$ with the criteria of "very good" c) the layout of accelerating the understanding gained the result is $100 \%$ with the criteria of "very good" d) typography of simple module content gained the result is $81.25 \%$ with the criteria of "good" e) easy-reading typography gained the result is $95.83 \%$ with the criteria of "very good" f) the content of typography facilitates the understanding gained the result is $75 \%$ with the criteria of "very good" g) the content of illustration gained the result is $83.33 \%$ with the criteria of "good". The total of the average based on designing learning media gained $90.83 \%$ with the criteria of "very good".

(3) The result of validity by graphic designer. The appropriateness of graphic design of learning media gained the total of average is $86.87 \%$ with the criteria of "very good". The aspect of assessment which is assessed on the graphic design of learning media consists of two aspects which are display and programming aspects. In the display aspect gained the average is $85.41 \%$ with the criteria of "very good" and programming aspect gained the average is $89.06 \%$ with the criteria of "very good".

(4) The result of research which was conducted by two Indonesian language teachers gained the result of average is $81.77 \%$ with the criteria of "good". In the teachers assessment consisted of four aspects which were assessed, such as, the appropriateness of content aspect, learning presentation, language and graphics. From all aspects gained the result of "good" criteria. Based on the appropriateness of content aspect gained the average is $80.20 \%$ with the criteria of "good", the assessment of learning presentation gained the average is $81.25 \%$ with the criteria of "good". Then, the language assessment gained the average is 81.25 with the criteria of "good" and the graphics assessment gained the average is $93.75 \%$ with the criteria of "good". The result of appropriateness assessment towards learning media of story fantasy text with character education-based has been appropriate to be used and has fulfilled the assessment terms on the validity stage by the material expert, media designer, and graphic designer of learning media with the positive result by the teachers assessment toward the media which all of the assessments gained the total of the average which fulfilled the criteria of "very good".

3. The Result of The Effectiveness of UsingFantasy Story Learning Media with Character Education for Seventh Grade Students at MTS Miftahussalam Medan
The Result of the effectiveness of using leaning media which was developed on the fantasystory materials with character education-based for Seventh Grade Students at MTS Miftahussalam Medan applied the Web-based learning media under category of "very good". The result of study can be seen from the average which is gained by the students after using the developed learning media. There are differences from the average of students' score both before and after using the developed learning media. The average score of students before using the developed learning media is 70.28, while the average score of students after using the developed learning media is 84.07. This demonstrated that the result of students' learning both before and after using the learning media gained a significant increase, is $13.79 \%$.

\section{CONCLUSION}

Based on the formula, objective, result, and discussion of fantasy story web-based learning media with the character education which are proposed before, so it can be concluded, as follows:

(1) The result of learning media development in this research is WEB-based learning media which can be accessed through internet connection by address website: elsya.000webhostapp.com.

(2) The result of students' learning ability after using fantasy story web-based learning media with the character education in very good category because it has increased $13.79 \%$ from the previous score before using web-based learning media is 70.28 in good category, and after using, the average score becomes 84.07.

\section{SUGGESTION}

Based on the conclusion of the study and implication of study result, as follows:

(1) All this time learning activities still use media in the form of power points and other manual media such as manual books, so it is suggested to use story fantasy web-based learning media with the character education because this media can give feedback more to the students and positive response for students.

(2) The product research on the development of interactive teaching materials fantasy stories with character education in the form of web-based fantasy story learning media is expected to be used by future researchers. As a review to improve the effectiveness of learning media and it is expected that there will be development of other learning media outside of fantasy story learning which is developed.

(3) Considering the learning media which was developed in this research are feasible and succeed in improving the result of students' learning only at the level of field trials (35 students), so there is still a need for follow-up research at a wider level of trials and more samples. 


\section{REFERENCES}

[1] Jayanti, Tri. dkk. Pengembangan Buku Pengayaan Menulis Cerita Biografi Bermuatan Nilai-Nilai Pendidikan Karakter Bagi Peserta Didik Kelas VIII SMP.http://journal.unnes.ac.id/sju/index.php/seloka. Diaksesmaret 2017

[2] Kemdikbud. 2017. Buku Guru Bahasa Indonesia Edisi Revisi 2017. Jakarta: Kementerian Pendidikan dan Kebudayaan.

[3] Kumyati, dkk. Pengembangan Bahan Ajar Menggal iInformasi dari Teks Narasi Sejarah untuk Menanamkan Nilai-Nilai Karakter Pada Peserta Didik Kelas V Sekolah Dasar .http://jurnal.unissula.ac.id/index.php/pendas/article/view/746

[4] Prastowo, Andi. 2011. Panduan Kreatif Membuat Bahan Ajar Inovatif Menciptakan Metode Pembelajaran yang Menarik dan Menyenangkan. Yogyakarta : Diva Press

[5] Tegeh, I Made. 2008. Media Pembelajaran. Singaraja: Institut Keguruan dan Ilmu Pendidikan Negeri Singaraja.

[6] Tomlinson, Brian. (ed.). 1998. Materials Development in Language Teaching. Cambridge: CUP. 